\title{
Identification of Leishmania (Leishmania) chagasi Isolated from Healthy Skin of Symptomatic and Asymptomatic Dogs Seropositive for Leishmaniasis in the Municipality of Rio de Janeiro, Brazil
}

\author{
Maria de Fátima Madeira, Armando de \\ Oliveira Schubach, Tânia Maria Pacheco \\ Schubach, Cristianni Antunes Leal and \\ Mauro Célio de Almeida Marzochi
}

\author{
Department of Micro-Imuno-Parasitology of the \\ Institute of Clinical Research Evandro Chagas, \\ Oswaldo Cruz Foundation, Rio de Janeiro/RJ, Brazil
}

\begin{abstract}
Euthanasia of seropositive dogs has been one of the principal measures adopted by the Program for the Control of Leishmaniasis in Brazil for many years. However, its efficacy is currently being questioned. We obtained intact skin samples from 20 Leishmania-reactive dogs from the municipality of Rio de Janeiro that had been referred for euthanasia. The promastigote forms of Leishmania were isolated in culture from 18 of these animals. Fourteen of these isolates were identified as Leishmania (Leishmania) chagasi by isoenzyme electrophoresis; seven of these were from asymptomatic dogs and seven were from symptomatic animals with visceral leishmaniasis. In conclusion, cutaneous parasitism is found in the intact skin of dogs naturally infected with $L$. (L.) chagasi, irrespective of the presence or absence of clinical signs suggestive of visceral leishmaniasis.
\end{abstract}

Key Words: Leishmania (Leishmania) chagasi, isoenzymes, dog, intact skin, clinical signs.

In Brazil, the Program for the Control of Leishmaniasis has adopted the measures recommended by the World Health Organization for many years, i.e., detection and treatment of human cases and control of the vector population and domestic reservoirs [1]. From the 50 s to the end of the $90 \mathrm{~s}$, the program was the responsibility of the federal government. Recently, as a result of the decentralization of the control programs for epidemics, the control of leishmaniasis has become the responsibility of the municipality [2,3]. This control is mainly based on the interruption of the transmission cycle, using direct measures involving the main vector, Lutzomyia longipalpis (Diptera: Psychodidae) and the

Received on 10 July 2004; revised 23 October 2004.

Address for correspondence: Dr. Maria de Fátima Madeira, Fundação Osvaldo Cruz - Instituto de Pesquisa Clínica Eduardo Chagas, Depto. Parasitologia, Av Brasil, 4365, Rio de Janeiro - RJ, Brazil. CEP: 21045-900. Tel/fax:55-19-3788-7727

The Brazilian Journal of Infectious Diseases 2004;8(6):440-444 (C) 2004 by The Brazilian Journal of Infectious Diseases and Contexto Publishing. All rights reserved. domestic dog; dogs were first reported to be infected in Northeast Brazil by Chagas et al. [4]. Within this context, dogs have been the target of these actions since the 50s, based on evidence showing their involvement in the transmission cycle of visceral leishmaniasis (VL) [5-7]. Thus, the detection and elimination of seropositive dogs has been a priority in several Brazilian municipalities; however, the efficacy of this approach is currently being questioned $[8,9]$.

In Rio de Janeiro, canine serological surveys were introduced in 1977 after the demonstration of the first autochthonous case of human VL [6]. At present, these surveys are routinely performed at six-month intervals in 31 locations in the region of the Gericinó and Pedra Branca massifs, where cases of American tegumentary leishmaniasis (ATL) have also been reported [10]. However, diagnostic confirmation of the animals' seropositivity by parasitological methods is usually not part of these surveys. The parasitological diagnosis, and the identification of the isolated parasites, are becoming increasingly more necessary to support discussions on the effectiveness of the strategy of 
eliminating seropositive dogs, which has been questioned as a control measure.

Twenty seropositive dogs with and without clinical signs of VL referred for euthanasia were studied to check for Leishmania in intact skin and to identify eventual isolates using enzyme electrophoresis analysis.

\section{Material and Methods}

Twenty dogs reactive to the Indirect Fluorescent Antibody Test (IFAT) were identified and collected by the Program for the Control of Leishmaniasis of the city of Rio de Janeiro between 1998 and 1999. The serological titers obtained with IFAT were 1:80 (one dog), 1:160 (one dog), 1:320 (five dogs), 1:640 (seven dogs), and 1:1280 (six dogs).

Dogs showing at least two of the following clinical signs were considered to be symptomatic: marked weight loss, alopecia in any body region, dermatitis, or presence of ocular secretion. Animals without these signs were considered to be asymptomatic.

The animals were sacrificed at the Jorge Vaitsman Municipal Institute of Medicine Veterinary (Rio de Janeiro, Brazil) and intact skin samples were removed from the abdominal region. The skin fragments were stored in sterile $0.85 \% \mathrm{NaCl}$ containing an antibiotic $(1,000 \mathrm{U} / \mathrm{mL}$ penicillin) and an antifungal agent $(50 \mu \mathrm{g} /$ $\mathrm{mL} 5$ ' fluorocytosine), for $24 \mathrm{~h}$ at $4^{\circ} \mathrm{C}$. After this period, the fragments were cut and seeded onto biphasic culture medium (NNN added to Schneider's medium supplemented with $10 \%$ fetal bovine serum - FBS). Isolation of the promastigote forms was assessed by direct visualization under a light microscope. During the logarithmic growth phase, parasites were transferred to $250-\mathrm{mL}$ culture flasks containing Schneider's medium supplemented with $20 \%$ FBS for mass parasite cultivation. Parasites were then washed in buffer $(0.85 \% \mathrm{NaCl}, 0.01 \mathrm{M}$ EDTA, $\mathrm{pH}$ 8.0) and stored in liquid nitrogen.

Enzyme electrophoresis was performed as described by Cupollilo et al. [11], using the following enzymes: 6PGDH (E.C.1.1.1.43), G6PDH (E.C.1.1.1.49), PGM (E.C.1.4.1.9), NH
(E.C.3.2.2.1), GPI (E.C.5.3.1.9), $\mathrm{MDH}$ (E.C.1.1.1.37), IDHNADP (E.C.1.1.42), and ME (E.C.1.1.1.40). Reference strains of Leishmania (Viannia) braziliensis (MHOM/BR/75/M2903), Leishmania (Leishmania) amazonensis (IFLA/BR/ 67/PH8) and Leishmania (Leishmania) chagasi (MHOM/BR/74/PP75) were used for comparison.

\section{Results}

The 20 animals were from localities close to the southern slope of the Pedra Branca massif (Barra de Guaratiba, Grumari, Vargem Grande and Ilha de Guaratiba). Eleven of the 20 dogs were classified as asymptomatic and nine as symptomatic. None of the dogs presented cutaneous lesions. Promastigote forms were isolated in culture from 18 animals, including nine symptomatic and nine asymptomatic dogs. Fourteen of the 18 isolates were identified as L. (L.) chagasi; seven were from symptomatic animals with VL and seven from asymptomatic ones (Table 1).

\section{Discussion}

Of 18 samples isolated from the intact skin of seropositive dogs, including nine symptomatic and nine asymptomatic animals referred for euthanasia, 14 were identified as $L$. (L.) chagasi, the only species recognized as a causative agent of VL in Brazil. Deane $\&$ Deane [12] had already demonstrated cutaneous parasitism in naturally infected dogs. In Brazil, the elimination of seropositive $\operatorname{dog} s$ has been recommended as a complementary measure for the control of leishmaniasis, in parallel with combating the vector $[1,7]$. This practice is based on the known infectivity of dogs parasitologically positive for $L$. longipalpis [13] and on the positive correlation between serological titers and parasitological positivity [14]. However, we found no correlation between clinical manifestations and the detection of the parasite in the skin. In the case of two asymptomatic dogs, with titers of 1:320 and 1:640, no parasites were isolated; 
Table 1. Serological and parasitological data obtained for 20 leishmania-seropositive dogs originating from different localities in the municipality of Rio de Janeiro sacrificed by the Program for the Control of Leishmaniasis/RJ, Brazil

\begin{tabular}{|c|c|c|c|c|}
\hline Dog code & $\begin{array}{c}\text { Serological } \\
\text { titers (IFAT)\# }\end{array}$ & Clinical status & $\begin{array}{l}\text { Parasitological } \\
\text { test (skin biopsy) }\end{array}$ & $\begin{array}{l}\text { Endemic } \\
\text { area }\end{array}$ \\
\hline P4 & $1: 320$ & A & Negative & B. de Guaratiba \\
\hline P8** & $1: 640$ & $\mathrm{~S}$ & Positive & B. de Guaratiba \\
\hline $\mathrm{P} 37 *$ & $1: 320$ & $\mathrm{~S}$ & Positive & B. de Guaratiba \\
\hline $\mathrm{P} 46 * *$ & $1: 320$ & A & Positive & B. de Guaratiba \\
\hline P67* & $1: 320$ & $\mathrm{~S}$ & Positive & B. de Guaratiba \\
\hline P70* & $1: 320$ & A & Positive & B. de Guaratiba \\
\hline P138* & $1: 1280$ & $\mathrm{~S}$ & Positive & Grumari \\
\hline P139* & $1: 160$ & A & Positive & Grumari \\
\hline $\mathrm{P} 140 *$ & $1: 80$ & A & Positive & Grumari \\
\hline $\mathrm{P} 141 *$ & $1: 1280$ & $\mathrm{~S}$ & Positive & Grumari \\
\hline P142* & $1: 1280$ & $\mathrm{~S}$ & Positive & Grumari \\
\hline $\mathrm{P} 143^{*}$ & $1: 1280$ & $\mathrm{~S}$ & Positive & Grumari \\
\hline P144* & $1: 1280$ & A & Positive & B. de Guaratiba \\
\hline P145* & $1: 640$ & $\mathrm{~S}$ & Positive & B. de Guaratiba \\
\hline P146** & $1: 1280$ & $\mathrm{~S}$ & Positive & Grumari \\
\hline P147* & $1: 640$ & A & Positive & Vargem Grande \\
\hline $\mathrm{P} 148 * *$ & $1: 640$ & A & Positive & I. de Guaratiba \\
\hline P149* & $1: 640$ & A & Positivo & I. de Guaratiba \\
\hline P150 & $1: 640$ & A & Negative & B. de Guaratiba \\
\hline $\mathrm{P} 151 *$ & $1: 640$ & A & Positive & Grumari \\
\hline
\end{tabular}

*(Samples analyzed by enzyme electrophoresis), A (asymptomatic), S (symptomatic).

\#IFAT (Indirect Fluorescent Antibody Test). Data obtained from the Municipal Health Secretary, Rio de Janeiro, Brazil.

** (Culture loss due to contamination).

however infection cannot be excluded, because other organs had not been investigated.

In the municipality of Rio de Janeiro, transmission areas of $L$. (V.) braziliensis and L. (L.) chagasi overlap [10], with possible involvement of domestic dogs in both transmission cycles [6]. Infection of these animals with $L$. (V.) braziliensis is associated with a low-level humoral immune response and the presence of cutaneous ulcers, without impairment of the general condition. In contrast, infection with $L$. (L.) chagasi can result in chronic systemic disease, characterized by variable clinical manifestations and a strong humoral immune response, the latter being the determinant factor in the identification and consequent elimination of seropositive animals. However, a positive canine serological exam does not permit discrimination between VL and ATL. In the latter case, there is little evidence suggesting that the domestic dog is a reservoir [15] and no recommendations regarding euthanasia exist. Elevated serological titers are not always associated with clinical signs of VL. Additionally, higher serological titers can be observed in ATL caused by $L$. (V.) braziliensis, especially when the mucosa of the upper airways is involved $[16,17]$. 
Despite the importance of canine disease in the municipality of Riode Janeiro, few studies characterizing the isolates obtained from seropositive animals have been carried out $[18,6]$. We found no phenotypic variability in any of the enzymatic systems. Lopes et al. [18], who analyzed canine and human isolates by enzyme and kinetoplast DNA electrophoretic analysis, reported the circulation of the same zymodeme and schizodeme of $L$. (L.) chagasi among human and canine populations; the authors drew attention to the fact that this animal might be a link in the cycle of domestic transmission. Our finding of L. (L.) chagasi in the intact abdominal skin of domestic dogs supports the hypothesis that these animals are probably the source of infection for the sand fly vector in peri-urban areas of the Municipality of Rio de Janeiro.

Cutaneous alterations have been frequently reported in canine visceral leishmaniasis, although we only collected cutaneous samples in a normal area of the abdomen. This region was chosen in attempt to prevent contamination of the culture, as it is an area with little fur. Nevertheless, Travi et al. [19] demonstrated that the skin of the ear was more infective to sand flies than that of the abdomen. However, little is know about the dissemination of $L$. (L.) chagasi in the skin of symptomatic and asymptomatic dogs; we isolated promastigote forms from 16 of 20 animals, independent of immunological status.

The strategy of eliminating seropositive dogs is currently a polemic subject and has been the cause of heated debate. In fact, parasitological confirmation followed by the identification and determination of phenotypic and genotypic parasite variability are of fundamental importance for epidemiological studies, permitting the identification of the circulating Leishmania species and of the relationship between the vector and human and animal hosts. Additional studies will be necessary to better understand the role of the domestic dog in the transmission cycles of VL and ATL.

\section{Acknowledgments}

We thank the Zoonoses Control Center (Rio de Janeiro), Jorge Vaitsman Municipal Institute of
Veterinary Medicine and the Program for the Control of Leishmaniasis of Rio de Janeiro for help with the identification and the sacrifice of the animals.

\section{References}

1. World Health Organization. Control of Leishmaniases. Technical Report Series - 793, Geneva, 1990.

2. Lacerda M. The brazilian leishmaniasis control program. Mem Inst Oswaldo Cruz 1994;89:489-95.

3. Furtado V.J.B., Coelho E.G. Leishmaniose visceral ou calazar: aspectos epidemiológicos e de controle. Rev Soc Bras Med Trop 1998;31:85-92.

4. Chagas E., Cunha A.M., Ferreira L.C., et al. Leishmaniose visceral americana (relatório dos trabalhos pela Comissão encarregada do estudo da leishmaniose visceral americana em 1937. Mem Inst Oswaldo Cruz 1938; 33:89-229.

5. Alencar J.E., Cunha R.V. Inquérito sobre o calazar no Ceará. Novos resultados.Rev Bras Malariol Doenças Trop 1963; $15: 391-403$.

6. Marzochi M.C.A., Coutinho S.G., Souza W.J., et al. Canine visceral Leishmaniasis in Rio de Janeiro, Brazil. Clinical, parasitological, therapeutical and epidemiological findings (1977-1983). Mem Inst Oswaldo Cruz 1985;80:349-57.

7. Ministério da Saúde, Secretaria de Vigilância em Saúde, Departamento de Vigilância Epidemiológica. Manual de Vigilância e controle da Leishmaniose visceral. Editora MS, Brasília, 2003.

8. Arias J.R., Monteiro P., Zicker F. The re-emergence of visceral leishmaniasis in Brazil. Emerg Infect Dis 1996; 2:145-6.

9. Costa C.H.N. Mudanças no controle da leishmaniose visceral no Brasil. Informe Técnico. Rev Soc Bras Med Trop 2001;34:223-8.

10. Kawa H., Sabroza P.C. Espacialização da leishmaniose tegumentar na cidade do Rio de Janeiro. Cad Saúde Pública 2002; 18:853-65.

11. Cupollilo E., Grimaldi G. Jr., Momen H.A general classification of new world Leishmania using numerical zymotaxinomy. Am J Trop Med Hyg 1994;50:296-311.

12. Deane L.M., Deane M.P. Leishmaniose visceral urbana (no cão e no homem) em Sobral, Ceará. O Hosp 1955; $47: 75-87$.

13. Deane M.P., Deane L.M. Infecção experimental do Phebotomus longipalpis em raposa (Lycalopex vetulus) naturalmente infectada pela $L$. donovani. O Hosp 1954; $46: 651-3$. 
14. Brener Z. Calazar canino em Minas Gerais. Tese de mestrado da Fac Med Univ Minas gerais, Belo Horizonte, 1957.

15. Reithinger R., Davies C.R. Is the domestic dog (Canis familiaris) a reservoir host of American cutaneous leishmaniasis? A critical review of the current evidence. Am J Trop Med Hyg 2001;61:530-41.

16. Pirmez C., Coutinho S.G., Marzochi M.C.A., et al. Canine american cutaneous leishmaniasis: a clinical and immunological study in dogs naturally infected with Leishmania braziliensis braziliensis in an endemic area of Rio de Janeiro. Am J Trop Med Hyg 1988;38:52-8.

17. Madeira M.F., Uchoa C.M.A., Leal C.A., et al. Leishmania (Viannia) braziliensis em cães naturalmente infectados. Rev Soc Bras Med Trop 2003;36:551-5.

18. Lopes U.G., Momen H., Grimaldi G., et al. Schizodeme and zymodeme characterization of Leishmania in the investigation of foci of visceral and cutaneous Leishmaniasis. J Parasitol 1984;70:89-98.

19. Travi B.L., Tabares C.J., Cadena H., et al. Canine visceral leishmaniasis in Colombia. Relationship between clinical and parasitologic status and infectivity for sand flies. Am J Trop Med Hyg 2001;64:119-24. 